\title{
A NOTE ON THE NAME STREPTOCOCCUS AGALACTIAE LEHMANN AND NEUMANN
}

P. Arne Hansen

Live Stock Sanitary Service and the Department of Bacteriology, University of Maryland, College Park, Maryland, U. S. A.

The correctness of the name Streptococcusagalactiae Lehmann and Neumann 1896 has recently been questioned by Professor Haupt (1) who wishes to replace it with Streptococcus agalactiae (Kitt 1893) Haupt 1952. The status of the species and its proper name was considered by Hansen (2) 1935, who pointed out that the oldest valid name was Streptococcus nocardi Trevisan 1889 (3). However, this name has never gained any usage in the literature, while Streptococcus agalactiae Lehmann and Neumann (4) has come into wide use since it was proposed in 1896. In spite of the, in part, faulty des cription of the organism, Hansen (2) recommended the continued use of Streptococcus agalactiae Lehmann and Neumann, this being after Streptococcus nocar $d i$, the next name which is indisputably a binomial. He emended the previous description of the organism with observations based on his original research, agreeing in all essentials with the work of Nocard and Mollereau (5), (6), (7), (8), Orla-Jensen (9), Ayers and Mudge (10), and Klimmer and Haupt (11).

It is admitted that Kitt (12) 1893 furnished, for his time, an excellent diagnosis of the species, in fact his description is much better than the one by Lehmann and Neumann (4); however, he used Streptococcus agalactiae contagiosae. Hence it is not correct to place Kitt's name after the combination $S t r e p t o c o c c u s$ agalactiae. A trinomial is invalid as a name for a species no matter what kind of description is attached. Reference is made to Chapter 3, Rule 6: "Names of species are binary combinations consisting of the name of the genus followed by a single specific epithet. If an epithet consists of two 
or more words, these must either be united or joined by hyphen.... "and to Rule 24: "A name must be rejected if it is illegitimate, i.e., if it is contrary to a rule. The publication of an epithet in an illegitimate combination must not be taken into consideration for purposes of priority.... "and furthermore to Rule 15: "For the indication of the name (unitary, binary, or ternary) of a group to be accurate and complete, and in order that the date may be readily verified, it is necessary to cite the author who first published the name in question." Hence, Kitt's name can be cited only in the event that agalactiae contagios a e is considered as a single epithet in which case it must be hyphenated or united giving the species name agalactiae -contagiosae. This would create a most undesir able precedent. A flood of cumbersome names will enter bacteriological literature if trinomials easily can be changed to binomials by mere hyphenation. Bacteriologists more than any other group of biologists have used descriptive Latin phrases in naming species.

Were one to agree with Profess or Haupt that the name given by Lehmann and Neumann is a cause of confusion, because of the faulty description that accompanied it, the only alternative that is in strict accord with the rules of nomenclature would be to discard agalactiae altogether and go back to the older name Streptococcus nocardi Trevisan. Trevisan refers to the correct description by Nocard and Mollereau, and De Toni and Trevisan (13) the same year use this name accompanied by a description based on Nocard and Mollereau's work. In the opinion of this author, it would seem more practical to retain the name Streptococcus agalactiae Lehmann and Neumann, and to emend their description according to the best knowledge of the present day; rather than to resurrect the correct but long forgotten name nocardi, which has never come into general use.

\section{REFERENCES}

(1) Haupt, H. The correct species name of the Streptococcus of bovine mastitis. Int. Bul. Bact. Nomen. and 
Tax. 2:104-106. 1952.

(2) Hansen, P. A. Mastitis III. The identity of Streptococcus agalactiae. N. Y. State Agr. Exp. St., Tech. Bul. 232. 1935 .

(3) Trevisan, V. I generi e le specie delle Batteriacee. Milano: L. Zanaboni e Gabuzzi. p. 30. 1889.

(4) Lehmann, K. B. and Neumann, R. Atlas and Grundriss der Bakteriologie und Lehrbuch der speciellen bakteriologischen Diagnostik I and II. Munich: J. F. Lehmann. p. 126. 1896.

(5) Nocard and Mollereau. Sur une mammite contagieuse des vaches laitière. Société centrale d. méd. vét. Bul. et Mem. N.S., 2:308-314. 1884.

(6) Nocard and Mollereau. Mammitecontagieuse. Société centrale d. méd. vét. Bul. et Mem. N. S. , 3:296-302. 1885.

(7) Nocard and Mollereau. Sur la mammite contagieuse. Société centrale d. méd. vét. Bul. et Mem. N. S., $3: 437-440$. 1885 .

(8) Nocard and Mollereau. Sur une mammite contagieuse des vaches laitieres. Ann. Past., 1:109-126. 1887.

(9) Orla-Jensen, S. The lactic acid bacteria. Mem. acad. roy. sci. Danemark, Sect. sci., 8 ser., 2:79-197.1919.

(10)Ayers, S. H. and Mudge, C. S. The Streptococci of the bovine udder. J. Inf. Dis., 31:40-50.1922.

(11)Klimmer, M. and Haupt, H. Die Streptokokkenmastitis (der gelbe Galt) der Rinder. Ergebnisse d. Hyg. Bakteriol. Immunitätsforsch. u. exp. Therapie, 11: 354-446. 1930.

(12)Kitt, T. Bacterienkunde und pathologische Mikroskopie für Tierärzte und Studierende der Tiermedicin, 2nd ed. Vienna: Perles. 1893.

(13)De Toni, J. B. and Trevisan, V. Schizomycetaceae ex Saccardo. Syll. Fung. Vol, VIII, Patavii, Decembri p. 1058.1889. 
